
\title{
CHEMICAL COMPOSITION AND SAMPLE PREPARATION OF ARCHAEOLOGICAL
WOOD FOR RADIOCARBON DATING
}

\section{G. I. ZAITSEVA}

The Institute of the History of Material Culture of the Russian Academy of Sciences

Dvortsovaya Naberezhnaya 18, St. Petersburg 191065 Russia

\begin{abstract}
The chemical composition of wood from archaeological sites differs from that of modern wood. The chemical changes depend on the microenvironment of the surrounding matrix more than the time of preservation. Chemical treatment of decomposed wood results in a great loss of initial material. The degree of wood decomposition should be taken into account most cellulose totally decom for ${ }^{14} \mathrm{C}$ dating. The main fraction of archaeological decomposed wood is a degraded lignin, with most cellulose totally decomposed. Nevertheless, decomposed wood can be a reliable material for ${ }^{14} \mathrm{C}$ dating archaeological without influencing through sample preparation can be reduced by using fairly weak concentrations of chemical reagents
\end{abstract}

\section{INTRODUCTION}

Wood is an important material used for radiocarbon dating archaeological cultures. The reliability of the dating method depends on the chemical treatment of the sample. A sample is treated to remove any external ${ }^{14} \mathrm{C}$ from the sample while leaving reliable fractions for dating. Wood cellulose is such a fraction, and it is used for high-precision measurement of ${ }^{14} \mathrm{C}$ in dendrochronological and astrophysical research (Stuiver and Becker 1993). As a rule, traditional pre-treatment methods are based on the sequential treatment of wood samples by acid and alkali solutions. The concentration of reagents varies from 1-4\% (Arslanov 1987; Kromer and Becker 1993). Difficulties occur when decomposed archaeological wood is used for dating. The losses of material in chemical pretreatment may reach $70-80 \%$, mainly during the alkali stage, and sometimes all the wood dissolves in the alkali solution. Why do these losses occur and can we reduce the losses without influencing the reliability of the dates? What fractions of decomposed wood are dated? The answers to these questions were obtained by studying the chemical changes of archaeological wood. This resulted in modified chemical treatment methods for decomposed wood from archaeological sites.

\section{METHODS}

In our laboratory, I determined the chemical composition of wood by traditional methods used in wood chemistry (Nikitin and Obolenskaya 1978; Zaitseva and Markov 1983). After removing visible contaminants, the content of substances dissolved in hot water and ether was established. The amount of cellulose was determined after ether extraction by the delignification of wood with a 4:1 alcohol-nitric acid mixture (95\% ethanol and $1.4 \mathrm{~g} \mathrm{~cm}^{-3} \mathrm{HNO}_{3}$ ). This method is similar to the standard one using $\mathrm{ClO}_{2}$ in terms of precision of cellulose determination, but it is more suitable for material containing only a small amount of cellulose (Browning 1967; Obolenskaya and Elnizkaya 1991). The residue obtained after the extraction of polysaccharide by acid hydrolysis (using $72 \%$ $\mathrm{H}_{2} \mathrm{SO}_{4}$ at $25^{\circ} \mathrm{C}$ for $1 \mathrm{~h}$, followed by boiling for $1 \mathrm{~h}$ with $3 \% \mathrm{H}_{2} \mathrm{SO}_{4}$ ) is lignin, but for the decomposed wood, it is a mixture of lignin and the decomposition products of organic fractions, mainly lignin. The sum of components obtained by these methods does not equal $100 \%$ because of unidentified compounds dissolved in the alkali and acid solutions for which special methods should be employed. The solubility of the sample in alkali was determined according to the weight loss after boiling $1 \% \mathrm{NaOH}$. Normal wood is known to contain no humic acids, yet part of the material dissolves in alkali solution (12\%-20\% depending on the wood species). To characterize the chemical 
change, infrared (IR)-spectra analysis was used. The samples were ground, sieved through $0.1 \mathrm{~mm}$ diameter and pressed into pills with $\mathrm{KBr}$.

${ }^{14} \mathrm{C}$ dates were produced using liquid scintillation counting. Two-channel equipment with quartz vials of $3.2 \mathrm{ml}$ and $6.8 \mathrm{ml}$ capacities was used. No correction was made for isotopic fractionation. The standard used in Russia has a coefficient activity of $4.99 \pm 0.011$ to the international standard SRM-4990 (Arslanov 1987).

\section{Discussion}

Before considering the chemical composition of decomposed archaeological wood samples, one should consider the chemical composition of normal wood. Wood is a multicomponent system, mainly consisting of cellulose and lignin. Table 1 shows the main components (Sharkov and Kujbina 1976). The ratio of cellulose to lignin is $c a$. 1.6:1. The solubility in hot water and ether is minor. Table 2 shows the chemical composition of archaeological wood, including the ${ }^{14} \mathrm{C}$ dates on the fraction soluble in $1 \% \mathrm{NaOH}$. The provenience of the archaeological wood samples included soil, peat, permafrost, and no contact with soil (the famous burial mounds of Altai, Pazyryk and Arzhan). The wood samples were the remains of barrow ceilings, logs and wood products. The chemical composition of archaeological wood differs from the normal corresponding species; changes depend more on the provenience than on the length of preservation. Wood from peat contains a significant amount of cellulose compared with wood from soil. Wood from the Altai stone barrow, which had no contact with soil and which experienced low temperature even in summer, contains a considerable amount of cellulose after $2 \mathrm{ka}$. Wood from permafrost retains about half its initial amount of cellulose after $50 \mathrm{ka}$. The most significant changes of chemical composition are observed in archaeological wood preserved in sandy loam and loamy soils. Cellulose was practically eliminated and the main component of wood became an unhydrolyzable residue. The state of preservation of wood can be discerned by its physical appearance. Wood preserved in soil is brown and is easily destroyed. The loss of cellulose results in increased solubility of wood samples in $1 \% \mathrm{NaOH}$, which can be used to characterize the degree of wood decomposition (Fig. 1).

TABLE 1. Chemical Composition of Different Varieties of Normal Wood (\% based on the weight of the moisture-free wood) (from Sharkov 1976)

\begin{tabular}{lllll}
\hline Wood type & $\begin{array}{l}\text { Hot water } \\
\text { extract }\end{array}$ & $\begin{array}{l}\text { Ether } \\
\text { extract }\end{array}$ & Cellulose & Lignin \\
\hline Fir & 2.76 & 0.94 & 46.10 & 28.07 \\
Pine & 3.19 & 1.78 & 51.80 & 24.70 \\
Oak & 2.75 & 0.53 & 38.60 & 27.58 \\
Birch & 1.41 & 0.91 & 35.38 & 19.80 \\
Larch & 5.10 & 1.80 & 45.80 & 29.50 \\
\hline
\end{tabular}

As Table 2 shows, the main source of carbon for dating decomposed wood is unhydrolyzable residue. Is this component the most reliable material for dating? What components are extracted by chemical treatment? Answers have been found after supplementary research. Table 3 shows the effect of the reagent's concentration on the loss of material. The material investigated was (larch) wood from the Ashpil barrow located in the Krasnoyarsk region of Siberia (Le-2205). Table 2 shows its chemical composition: cellulose was $4.5 \%$, or $c a .10 \%$ of the initial amount of cellulose of normal larch (see Table 1). The loss of material results from the dissolution of unhydrolyzable residue during the alkali treatment. Half of the initial amount of residue dissolves in $1-3 \% \mathrm{NaOH}$ solutions. 


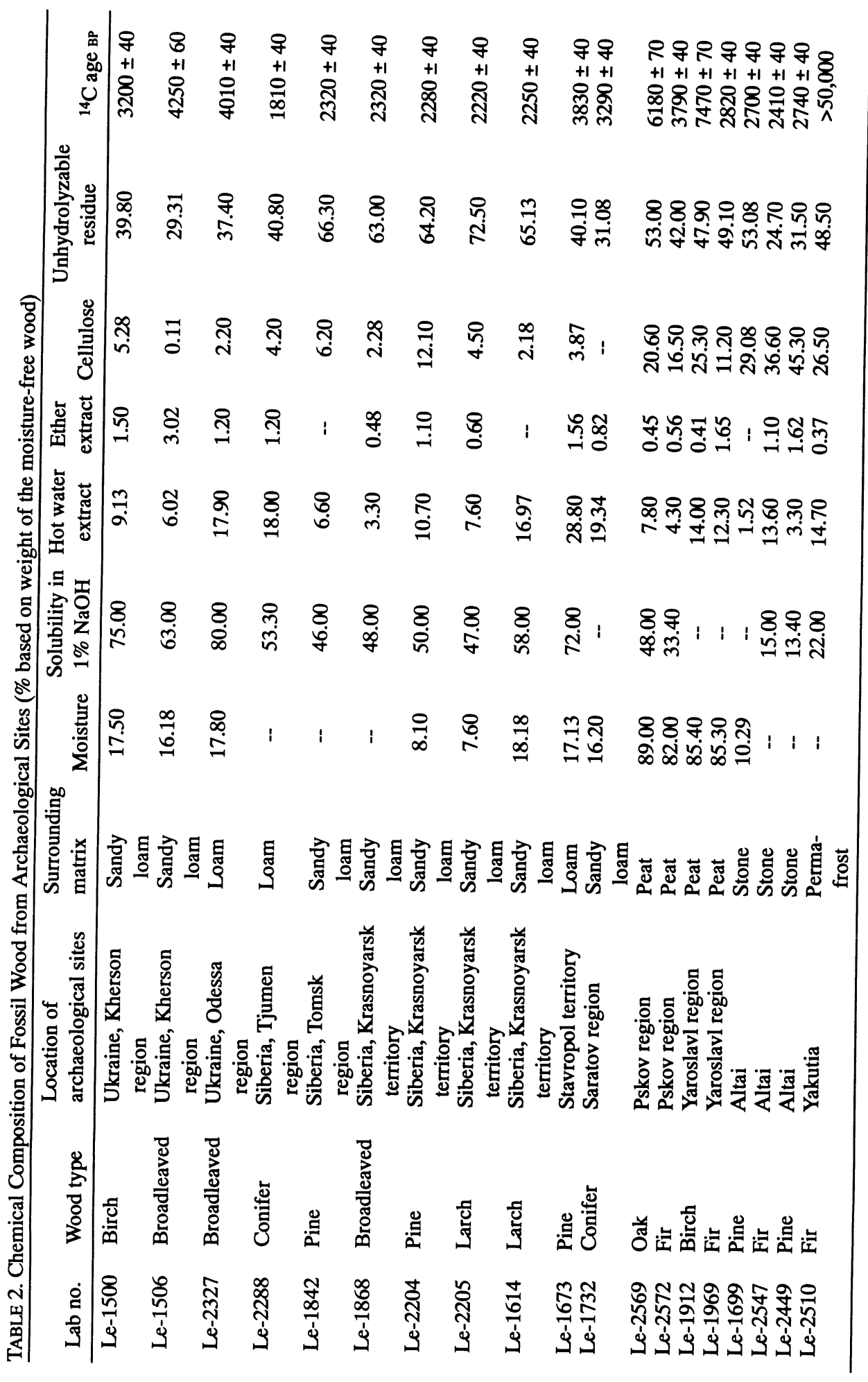




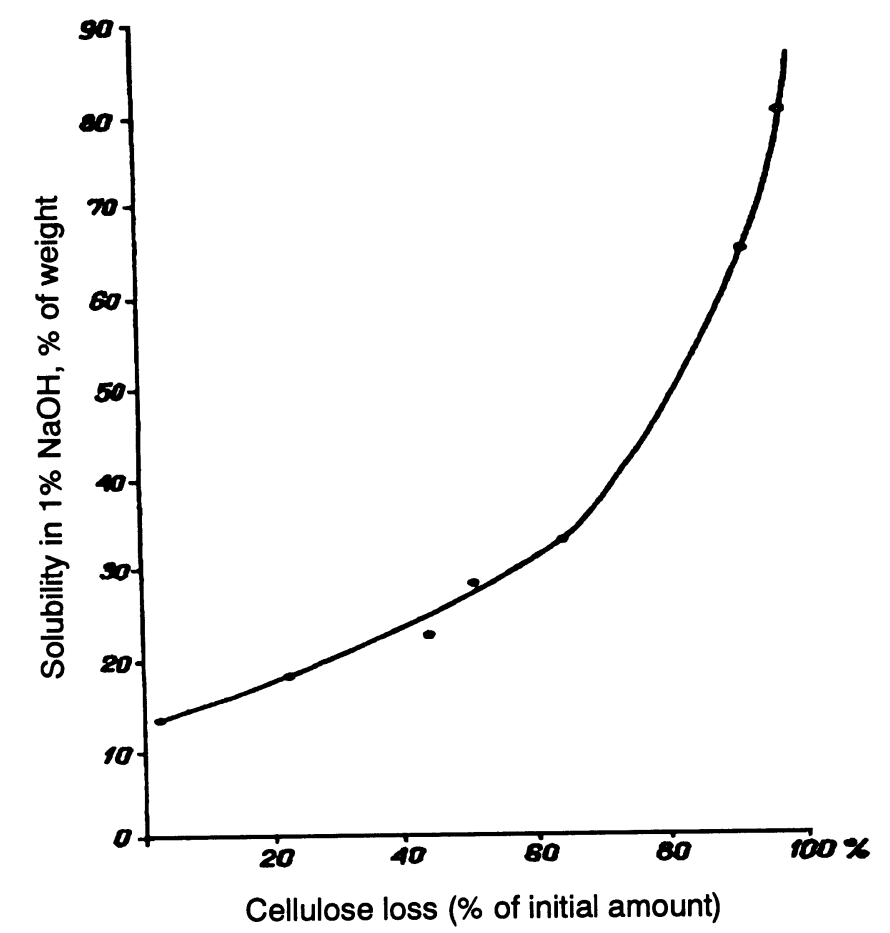

Fig. 1. Relation between archaeological wood solubility and remaining amount of cellulose

TABLE 3. Sample Loss (Le-2205), Treatment Method and Chemical Composition of Sample after Treatment (boiling for $1 \mathrm{~h}$ )

\begin{tabular}{|c|c|c|c|c|c|}
\hline \multirow[b]{2}{*}{$\begin{array}{l}\text { Reagent and its } \\
\text { concentration }\end{array}$} & \multirow{2}{*}{$\begin{array}{c}\text { Loss of } \\
\text { sample by } \\
\text { weight (\%) }\end{array}$} & \multicolumn{4}{|c|}{$\begin{array}{l}\text { Chemical composition after treatment } \\
\text { (\% based on the weight of moisture-free wood) }\end{array}$} \\
\hline & & $\begin{array}{l}\text { Hot-water } \\
\text { extract }\end{array}$ & $\begin{array}{c}\text { Ether } \\
\text { extract }\end{array}$ & Cellulose & $\begin{array}{c}\text { Unhydrolyzable } \\
\text { residue }\end{array}$ \\
\hline Initial sample & -- & 7.6 & 0.6 & 4.5 & 72.5 \\
\hline $0.5 \% \mathrm{HCl}$ & 3.0 & 1.5 & 0.7 & 0.6 & 69.6 \\
\hline $1.0 \% \mathrm{HCl}$ & 5.0 & 6.0 & 0.9 & 2.2 & 70.1 \\
\hline $3.0 \% \mathrm{HCl}$ & 13.0 & 5.1 & 0.7 & 2.0 & 66.7 \\
\hline $0.5 \% \mathrm{NaOH}$ & 36.6 & 9.2 & 0.4 & 0.9 & 58.9 \\
\hline $1.0 \% \mathrm{NaOH}$ & 47.0 & 7.7 & 0.2 & 0.5 & 32.1 \\
\hline $3.0 \% \mathrm{NaOH}$ & 56.0 & 0.2 & 0.2 & 0.3 & 33.7 \\
\hline
\end{tabular}

Thus, the main questions are what contaminants are contained in the residue and whether these admixtures influence the ${ }^{14} \mathrm{C}$ dates. One can assume that these admixtures are humic acids formed by the decomposition of fossil organic substances. The microorganisms and the chemical conditions of the environment are known to destroy organic material, and foreign carbon can be included in the molecule of humic acid.

The real problem is to establish whether humic acids can be formed at the stage of the decomposition of fossil organic material. The problem of the humification of organic fossil material is complex 
and has not yet been completely solved. Lignin is now considered unquestionably to be one of the sources forming humic acids (Manskaya and Kodina 1975). Cellulose disintegrates into ordinary products such as $\mathrm{CO}_{2}$ and different simple acids, which are eliminated from the open system. Lignin can be destroyed by microorganisms to form more complex compounds. Humic acids dissolve in alkali solutions and they may be original alkali-soluble substances, or may be products of lignin decomposition. I tried to answer this question by researching the sample of decomposed larch from the Ashpil barrow (Le-2205). Isolating humic acids involves boiling the sample in a $0.1 \mathrm{~N} \mathrm{NaOH}$ solution (Ponomareva and Plotnikov 1980). The humic acids are isolated by acidifying the alkali solution and centrifuging. The solubility of sample Le-2205 in $0.1 \mathrm{~N} \mathrm{NaOH}$ is $55.5 \%$. The yield of humic-like substances is $70 \%$ of the sum of soluble substances, or $37 \%$ of the initial moisture-free wood. The unhydrolyzable residue contains $40 \%$ remaining lignin, $37 \%$ humic-like substances and $23 \%$ unidentified soluble substances.

To identify the origin of lignin fractions, I analyzed the IR spectra and compared them with the spectra of normal wood and its lignin (Fig. 2). The spectra of archaeological wood are similar to those of modern larch lignin (Fig. 2: curves 1 and 3). The spectrum of lignin extracted from archaeological

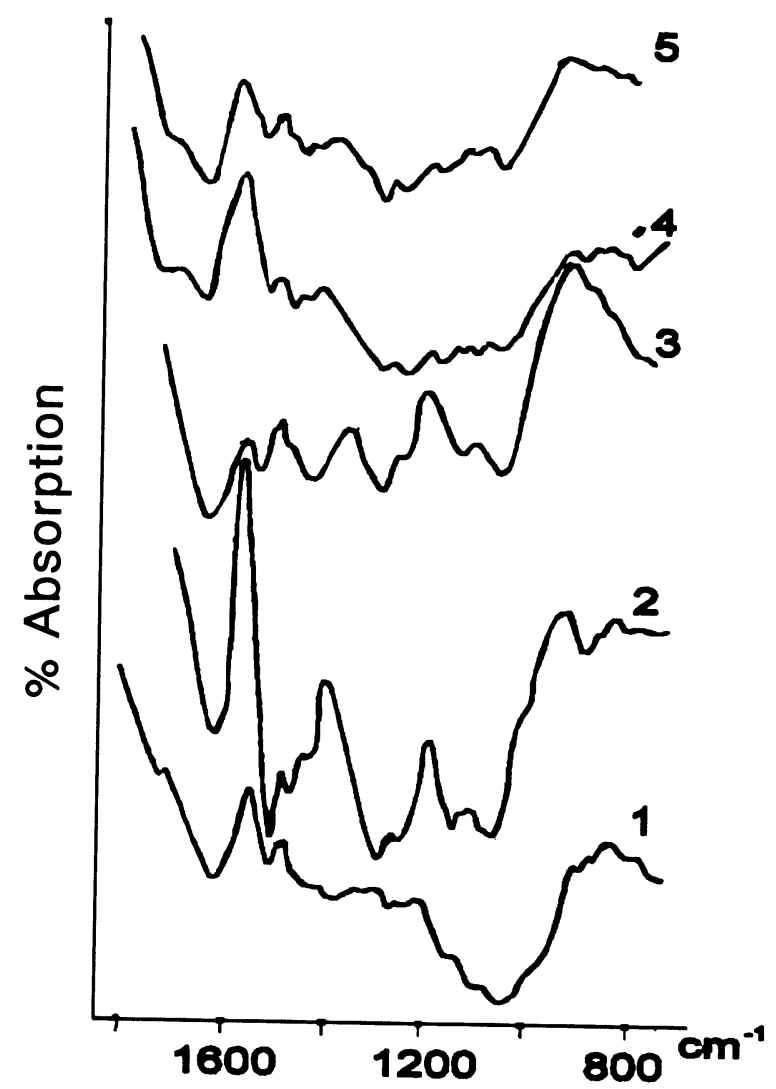

Fig. 2. Infrared spectra of normal and archaeological wood and their fractions: 1. normal larch wood; 2. lignin of larch; 3. archaeological larch wood (Le-2205); 4 . insoluble fraction in $1 \% \mathrm{NaOH}$ (lignin of archaeological wood); 5 . soluble fraction (lignoacids) 
wood by alkali treatment has lines characteristic of normal lignin, but their intensity is low. The spectrum of humic-like substances is similar to the spectrum of lignin of archaeological wood. This suggests a lignin origin for humic-like substances. I have named these "lignoacids" as the products of destroyed lignin available to dissolve in alkali solution. Lignoacids are extracted by alkali treatment and are the cause of material loss. Can they influence the ${ }^{14} \mathrm{C}$ age? Table 4 shows the results of ${ }^{14} \mathrm{C}$ dates of different fractions. One can see that there are no significant statistical differences between the ${ }^{14} \mathrm{C}$ ages of unhydrolyzable residue (the mixture of lignin and products of its decomposition) and isolated lignoacids. This fact tends to confirm the identical nature of these fractions, which, in all probability, are distinguished by molecular weight. It is interesting to note that a similar case can be observed in accelerator mass spectrometric dating of soluble and insoluble fractions (Segerberg and Possnert 1991).

TABLE 4. Results of ${ }^{14} \mathrm{C}$ Analysis and Loss of Material for Samples Treated with Different Reagents

\begin{tabular}{lcccc}
\hline & \multicolumn{2}{c}{ Le-1614 } & \multicolumn{2}{c}{ Le-1842 } \\
\cline { 2 - 5 } $\begin{array}{l}\text { Method of treatment } \\
\text { (boiling for } 1 \mathrm{~h} \text { ) }\end{array}$ & $\begin{array}{l}\text { Loss of sample } \\
\text { by weight (\%) }\end{array}$ & ${ }^{14} \mathrm{C}$ age BP & $\begin{array}{c}\text { Loss of sample } \\
\text { by weight (\%) }\end{array}$ & ${ }^{14} \mathrm{C}$ age BP \\
\hline $\mathrm{H}_{2} \mathrm{O}$ & 16.0 & $2210 \pm 40$ & 6.6 & $2310 \pm 40$ \\
$3 \% \mathrm{HCl}$ & 19.0 & $2250 \pm 40$ & 13.1 & $2290 \pm 40$ \\
$3 \% \mathrm{NaOH}:$ & 65.0 & & 52.0 & \\
insoluble fraction & $28.0^{*}$ & $2260 \pm 40$ & $30.0^{*}$ & $2330 \pm 40$ \\
soluble fraction & $22.0^{*}$ & $2170 \pm 40$ & $16.0^{*}$ & $2390 \pm 40$ \\
$0.5 \% \mathrm{HCl}+0.5 \% \mathrm{NaOH}$ & 42.0 & $2230 \pm 40$ & 30.0 & $2400 \pm 40$ \\
\hline
\end{tabular}

*Fraction yield (\%) based on the weight of moisture-free wood

Thus, the degree of wood decomposition should be taken into account when preparing the wood samples for ${ }^{14} \mathrm{C}$ dating. To diminish the loss of the initial amount of material, the concentration of chemical reagents must not be so strong as to destroy its structure. I prefer to use concentrations of acid and alkali not stronger than $0.5 \%$, when molecular organic contaminations can be extracted. This is very important for preserving small samples of archaeological wood for dating.

Considering that decomposed wood differs from normal wood, is it reliable for ${ }^{14} \mathrm{C}$ dating of archaeological cultures? There was a good opportunity to test this using samples from half-burned wood containing charcoal and decomposed wood. Charcoal is resistant to decomposition, whereas the wood had decomposed during preservation: it was brown and easily disintegrated. Archaeologists believe the wood was burned during the construction of the barrow. Table 5 shows the ${ }^{14} \mathrm{C}$ results.

TABLE 5. Results of ${ }^{14} \mathrm{C}$ Dating of Charcoal and Decomposed Wood from the Same Archaeological Site* (treatment with $0.5 \%$ acid-alkali solution)

\begin{tabular}{lll}
\hline Lab no & Material & ${ }^{14}$ C age BP \\
\hline Le-2008a & Charcoal (inner tree rings) & $2090 \pm 40$ \\
Le-2008b & Charcoal (middle tree rings) & $2080 \pm 40$ \\
Le-2008c & Charcoal (outside tree rings) & $2090 \pm 40$ \\
Le-2008d & Wood (all tree rings) & $2070 \pm 40$ \\
Le-2010 & Charcoal (all tree rings) & $1890 \pm 40$ \\
Le-2010b & Wood (all tree rings) & $1930 \pm 40$ \\
\hline
\end{tabular}

*Samples from barrow Medvedka II, Krasnoyarsk territory, near Abakan. Le-2008 = grave 1, north cell; Le-1010 = grave 1 , south cell 
The ${ }^{14} \mathrm{C}$ ages of both the charcoal and decomposed wood treated by acid-alkali solutions with $0.5 \%$ concentrations have no significant differences. In spite of their decomposition, wood samples can be as reliable for the ${ }^{14} \mathrm{C}$ dating of archaeological sites as charcoal.

\section{Conclusion}

The chemical composition of wood from archaeological sites differs from that of normal wood. One must take into account the degree of wood decomposition in preparing such samples for ${ }^{14} \mathrm{C}$ dating. Because decomposed wood contains little cellulose, the main fraction for dating is decomposed lignin. Hydrolysis of wood is known to proceed in both acid and alkali solutions. There can be no question that fossil decomposed wood is hydrolyzed more easily than normal, thereby causing the appreciable loss of material during chemical treatment. To diminish this loss, the concentration of acid and alkali should not be too strong. Decomposed wood does not contain foreign carbon contaminants and can be a reliable material for ${ }^{14} \mathrm{C}$ dating of archaeological samples.

\section{ACKNOWLEDGMENTS}

This work was supported by the Department of Wood Chemistry of the Forest-Technical Academy. Many thanks are due Dr. A. Obolenskaya, who helped to provide the chemical analysis and to discuss the results.

\section{REFERENCES}

Arslanov, Kh. A. 1987 Radiocarbon: Geochemistry and Geochronology. St. Petersburg, St. Petersburg University: 289 p. (in Russian).

Browning, B. L. 1967 Methods of Wood Chemistry. 2 vol. New York, Interscience Publishers: 882 p.

Kromer, B. and Becker, B. 1993 German oak and pine ${ }^{14} \mathrm{C}$ calibration,7200-9439 BC. In Stuiver, M., Long, A. and Kra, R., eds., Calibration 1993. Radiocarbon 35(1): 125-126.

Manskaya, S. M. and Kodina, L. A. 1975 The Geochemistry of Lignin. Moscow, Nauka: 374 p. (in Russian).

Nikitin, M. A. and Obolenskaya, A. V., eds. 1978 The Chemistry of Wood and Cellulose. Moscow, Forest Industry: 368 p. (in Russian).

Obolenskaya, A. V., Elnizkaya, Z. P. and Leonovich, A. A. 1991 Laboratory Research on Wood and Cellulose Chemistry. Moscow, Ecology: 320 p. (in Russian).
Ponomareva, V. V. and Plotnikov, G. A. 1980 Humus and the Formation of Soils. St. Petersburg, Nauka: 220 p. (in Russian).

Sharkov, V. I. and Kujbina, N. I., eds. 1976 Quantitative Chemical Analysis of Organic Material. Moscow, Forest Industry: 72 p. (in Russian)

Segerberg, A. and Possnert, G., eds. 1991 Ceramic chronology in view of ${ }^{14} \mathrm{C}$ datings. Laborativ Arckeologi 5:83-91.

Stuiver, M. and Becker, B. 1993 High-precision decadal calibration of the radiocarbon time scale $A D 1950$ 6000 BC. In Stuiver, M., Long, A. and Kra, R., eds., Calibration 1993. Radiocarbon 35(1): 35-65.

Zaitseva, G. I., Markov, Yu. N., Obolenskaya, A. V. 1983 Investigations of chemical composition of degraded wood from different archaeological sites. Khimiia Drevesiny 2: 112-116 (in Russian). 